\title{
Response of Integrated Nutrient Management on Babycorn (Zea mays L.) - A Review
}

\author{
Alka Jyoti Sharma ${ }^{1}$, M. K. Singh ${ }^{1 *}$, Nirpendra Pratap Singh ${ }^{1}$, \\ Sneha $^{2}$ and Akanksha Raj $^{2}$ \\ ${ }^{1}$ Department of Agronomy, Bihar Agricultural University Sabour, Bhagalpur, India \\ ${ }^{2}$ Department of Soil Science and Agricultural Chemistry, Bihar Agricultural University \\ Sabour, Bhagalpur, India \\ *Corresponding author
}

\section{A B S T R A C T}

\section{Keywords}

Maize cultivation,

Baby corn,

Scientific crop,

Chemical fertilizer

Article Info

Accepted:

26 April 2020

Available Online:

10 May 2020
Maize cultivation for vegetable purpose, such as baby corn is a diversified and value addition in food industries. Baby corn is the female inflorescence in the maize plant, harvested within two days of silk emergence and is sweet in taste and crisp which is a source of foreign earning exchange for India and successful in countries like Thailand and Taiwan has now proven to be a successful venture. The most crucial factors in scientific crop productions are nutrient management. In modern agriculture the knowledge of optimum dose of crop nutrition is of prime concern. The views of active investigators, theoreticians and practitioners on growth, yield, quality, nutrient uptake, soil health and economics of baby corn can be easily understood by this article. Maize and specialty corn requires very high quantities of nutrients during the period of efficient utilization and for gaining higher productivity because maize is the nutrient exhaustive crop. Through the application of chemical fertilizer can maximize the productivity of baby corn but in the long run it will impair the sustainability of growing field. Furthermore, substitution of some amount of chemical fertilizers with either organic source of nutrient along with biofertilizers can maintain economic stability of farmers and sustains soil health. Majorities of the researchers had suggested fertility level of $150-180 \mathrm{~kg}$ nitrogen, 60-90 kg $\mathrm{P}_{2} \mathrm{O}_{5}, 60-90 \mathrm{Kg} \mathrm{K}_{2} \mathrm{O}, 5-10 \mathrm{~kg} \mathrm{Zn}$ and 30-40 kg Sulphur ha ${ }^{-1}$ for higher baby corn yield, fodder yield, nutrient content and monetary returns to the growers. However, substitution of $25 \%$ nitrogen by organic sources viz., FYM/vermicompost along with biofertilizers was more beneficial for baby corn yield, fodder yield, economics and improvement of soil fertility status.

\section{Introduction}

Maize (Zea mays L.), considered as queen of cereals because of its highest yield potential among the cereal crops and one of the most important world cereals which serves as staple food crop for human being and feed for animals, also utilized as a source of raw material for the production of oil, protein, starch, food sweeteners and alcoholic beverages as well as fuel source. Maize originated from America and its cultivation was a successful venture in countries like Thailand and Taiwan despite being a recent development in India.

For obtaining more foreign earning as well as maximum returns to the growers now 
attention is being given by both scientist and farmers to find out its potentials. These are consumed by human beings as a source of cereal vegetable and after harvest the plant can be used as green fodder for animals adding more, the cultivation of baby corn can give double return to the farmer unlike normal grain maize. Baby corn is basically unfertilized young cobs harvested 2 or 3 days after silk emergence. At the global level it gained its popularity as an immature cereal vegetable, preferred due to shift in dietary habit from non-vegetarian to vegetarian also due to the enhancement of living standards. Since the manual method of harvesting is followed in baby corn and fortunately India has abundance in cheap labour thus this crop serve as the great potential for production and export (Dadarwal et al., 2009). Each hundred grams of baby corn are has its constituents in the form of $89.1 \%$ Moisture, $1.9 \mathrm{~g}$ Protein, 0.2 g Fat, $0.06 \mathrm{~g} \mathrm{Ash,} 8.2 \mathrm{mg}$ Carbohydrate, $28 \mathrm{mg}$ Calcium, $86 \mathrm{mg}$ Phosphorus and $11 \mathrm{mg}$ Ascorbic Acid (Thavaprakash et al., 2005) . The country leading in export of baby corn at the world level include Thailand, Sri Lanka, Taiwan, China, Zimbabwe, Zambia, South Africa, Nicaragua, Costa Rica and Guatamela and major importers of baby corn in the world are U.K., U.S.A., Malaysia, Japan and Australia. The application of inorganic fertilizers not only helps in obtaining maximum production of baby corn but it also increases the cost of production along with its hazardous effects on environmental health. So judicious uses of nutrients from alternative source like chemical, organic as well as biofertilisers will maintain the environmental sustainability for generations (Dadarwal et al., 2009). The adoption of INM practices on the field will reduce the cost of production and bringing the economic sustainability among the farmers. It also increases the supply and availability of nutrients to the crop as well as enhances the activity of beneficial soil microorganisms due to availability of more organic matter in soil. The example of chemical fertilizers include Urea, Muriate of Potash, Calcium Ammonium Nitrate, Diammonium Phosphate, Zinc Sulphate, and so on and for organic sources include Farm Yard Manure (FYM), Poultry Manure (PM), Compost, Goat Manure, Green Manure, etc. and the example of bio-fertilizers are Phosphate Solublizing Bacteria, Azolla, Biospirillum, Biopotash and so on. INM practices helps in increasing the economic yield of the farmers and also helpful in enhancing the nutrient availability to the crop and the enhanced organic matter content in the soil will be helpful in boosting the activity of beneficial soil micro organisms.

\section{Effect of inorganic fertilizers}

The most important nutrients in maize grown for baby corn production is Nitrogen. It is structural components of enzymes, alkaloids, nucleotides, chlorophyll, amino acids, protein molecules and other constituents, it plays a vital role in growth and development of plants. Phosphorus being the constituents of phosphatases, sugar, ADP and ATP plays an important role in energy transformations and it is also involved in the basic reactions of photosynthesis. Potassium involved in the synthesis of carbohydrates and resistance to diseases and adverse environmental conditions. It is crucial for the growth and reproductive development of plant parts and enhance the uptake and utilization of nitrogen and phosphorus. Potassium cation is most abundant in the cytoplasm that regulates osmotic potential of cells and tissues of glycophytic plant species. Sulphur has long been recognized as an essential element for plant and animal and it is known to be indispensable for many reactions of living cells and tissues. Zinc regulates various metabolic activities in plants essential for several enzymatic activation. It also plays a vital role in oxidation processes in plant cells, 
photosynthesis and nitrogen metabolism which ultimately increased the growth of the maize.

\section{Effect of N, P, K, S and Zn on Growth characters}

Vishalu et al., (2009) observed that plant height, total dry matter production and net assimilation rate of maize were significantly higher with application of 150-75-37.5 kg NPK ha $\left.{ }^{-1} 100-50-25 \mathrm{~kg} \mathrm{NPK} \mathrm{ha}^{-1}\right)$. Similarly, Ashoka et al., (2009) assessing the combined effect of macro and micro-nutrient application on baby corn cv. PAC-792 revealed that application of 150-75-45 kg NPK ha- ${ }^{-1}$ RDF) + ZnSO4@25 kg recorded significantly taller plants, number leaf plant $^{-1}$ and dry matter production plant ${ }^{-1}$ over RDF alone. Sobhana et al., (2012) conducted a field experiment at IARI New Delhi during kharif season of 2010 to assess the nutrient requirements of baby corn hybrid $\mathrm{HM}-4$ and noticed that each increase in NPK level from control to $187.5-32.75-62.5 \mathrm{~kg}$ NPK ha ${ }^{1}$ recorded significantly taller plants and higher dry weight plant- ${ }^{1}$ but LAI improved only up to application of $150-26.2-50 \mathrm{~kg}$ NPK ha ${ }^{-1}$ Lone et al., (2013) conducted field experiment at Srinagar, Kashmir, Jammu and Kashmir on baby corn, reported that application of 5t FYM+ $150 \%$ recommended dose of fertilizer $\left(225 \mathrm{~N}: 90 \mathrm{P}_{2} \mathrm{O}_{5}: 60 \mathrm{~kg} \mathrm{~K} 2 \mathrm{O}\right.$ $\mathrm{ha}^{-1}$ ) produced taller plants as compared to rest of the treatments. At Budgam, Kashmir Gul et al., (2015) reported that application of NPK 90-60-40 kg ha-1 and 75-50-30 kg haboth were at par and gave higher plant height, leaf area index, dry matter production at different growth stages of rainfed maize and significantly superior over the level of NPK 60-40-20 kg ha ${ }^{-1}$. Rasool et al., (2015) observed that $75 \%$ NPK + FYM $4.5 \mathrm{t} \mathrm{ha}^{-1}+$ biofertilizer significantly increased the plant height, leaf area index and dry matter accumulation, number of days taken to tasseling, silking and milky stages as compared to rest of the treatments. Further, Singh et al., (2016) carried out a field experiment on baby corn and reported that among nutrient management treatments, the integration of $5 \mathrm{t}$ FYM with $100 \mathrm{~kg}$ of inorganic $\mathrm{N}$ ha- ${ }^{1}$ significantly increased growth characters viz. plant height, number of leaves per plant, leaf area index and dry matter accumulation as compared to rest of the nutrient management treatments. While, Kumar et al., (2016) carried out a field experiment at Varanasi (UP) results reveals that application of $125 \%$ RDF significantly increased the root length, root dry weight and root volume of baby corn at respective stage of crop growth over 100\% RDF. Later on Sharma et al., (2019) reported that the different growth parameters viz., taller plants, LAI, number leaf plant $^{-1}$ and dry matter production plant $^{-1}$ of baby corn was improved with higher fertility level 180:90:90:5 kg $\mathrm{N}: \mathrm{P}_{2} \mathrm{O}_{5}: \mathrm{K}_{2} \mathrm{O}: 5 \mathrm{ha}^{-1}$ in the Indo Gangetic Plains of Bihar.

\section{Effect of N, P, K, S and Zn Yield attributes and yields}

Vishalu et al., (2009) observed yield attributing characters viz. cobs plant ${ }^{-1}$, cob length and girth as well as grain and stover yield of maize increased were significantly higher with application of 150-75-37.5 kg NPK ha ${ }^{-1}$ over 100-50-25 kg NPK ha- ${ }^{-1}$. While experimenting with baby corn, Ashoka et al., (2009) observed that on the application of RDF (150-75-45 kg NPK ha $\left.{ }^{-1}\right)+$ ZnSO4 @ $25 \mathrm{~kg} \mathrm{ha}^{-1}$ significantly enhanced the number of corn plant ${ }^{-1}$, corn weight, corn and green fodder yield over RDF alone. Similarly, Singh et al., (2010) from Varanasi reported that increase in baby cob weight, baby corn weight, cobs plant $^{-1}$, baby corn girth, baby cob yield, baby corn and green fodder yield were observed with application of 180-90-90 $\mathrm{kg} \mathrm{N}-\mathrm{P}-\mathrm{K} \mathrm{ha}^{-1}$ but remained statistically on 
par with 120-60-60 kg NPK ha-1. At Tuticorin (TN), Paramasivan et al., (2010) worked out to make the conclusion about the optimum dose of nutrient required for hybrid maize through balanced fertilization and noticed significantly maximum grain yield with increasing level of nutrient up to 250-64-48$4.8 \mathrm{~kg} \mathrm{NPKZn} \mathrm{ha}{ }^{-1}$. Later on Ashoka and Sunitha (2011) observed that significantly higher baby corn yield was recorded with the application of $100 \%$ RDF (150-60-40 kg NPK $\left.\mathrm{ha}^{-1}\right)+25 \mathrm{~kg} \mathrm{ZnSO} 4$ as compared to RDF (150-60-40 kg NPK $\mathrm{ha}^{-1}$ ) alone. At Coimbatore a field experiment was conducted to study the effect of balanced fertilization on maize by Paramasivan et al., (2011), they observed that successive increment in levels of NPKZn application up to 250-60-25-10 kg NPKZn ha ${ }^{-1}$ has significantly increased cob length and girth, grain and stover yield. After that Kumar and Bohra at Varanasi (2014) evaluated the effect of nitrogen, phosphorus and potassium (NPK) (100\% and $125 \%$ of the recommended dose of fertilizer), sulfur $(0,25$ and $50 \mathrm{~kg} \mathrm{~S}$ ha-1) and zinc (0, 5 and $10 \mathrm{~kg} \mathrm{Zn}$ $\mathrm{ha}^{-1}$ ) and found that the application of $125 \%$ RDF over $100 \%$ RDF resulted in significant growth in green leaves, stem girth, dry matter plant $^{-1}$, crop growth rate (CGR), chlorophyll content of leaves, other yield attributes like number of baby cobs plant ${ }^{-1}$, cob and corn weight, length and girth of corn as well as yield of cob, corn and green fodder. Adding more in 2014 Jeet et al., worked out to study the effect of four nitrogen levels $\left(0 \mathrm{~kg} \mathrm{~N} \mathrm{ha}^{-1}\right.$, $50 \mathrm{~kg} \mathrm{~N} \mathrm{ha}{ }^{-1}, 100 \mathrm{~kg} \mathrm{~N} \mathrm{ha}^{-1}$ and $150 \mathrm{~kg}$ $\left.\mathrm{N} \mathrm{ha}^{-1}\right)$ and three levels of sulphur $(15 \mathrm{~kg} \mathrm{~S}$ $\mathrm{ha}^{-1}, 30 \mathrm{~kg} \mathrm{~S} \mathrm{ha}^{-1}$ and $45 \mathrm{~kg} \mathrm{~S} \mathrm{ha}^{-1}$ ) in quality protein maize (QPM) and observed significantly highest plant height, leaf area index (LAI) and yield were recorded with 150 $\mathrm{kg} \mathrm{N} \mathrm{ha}{ }^{-1}$ as compared to N100, N50 and N0.In 2013 Kumar reported that cob, corn and green and dry fodder yield, net profit, nutrient content (NPKSZn) and their uptake were recorded significantly higher with application of $125 \%$ RDF. However later on application of $50 \mathrm{~kg} \mathrm{~S} \mathrm{ha}{ }^{-1}$ resulted in significant increase in cob, corn; green fodder yield, net profit and nutrient content and uptake of baby corn over the control treatment but it remained at par with $25 \mathrm{~kg} \mathrm{~S}$ $\mathrm{ha}^{-1}$. Similar result was also observed with application of graded zinc levels. Increasing levels of sulphur and zinc progressively improved fodder quality parameters of baby corn viz., crude protein, ash, Ca content except crude fibre content which followed opposite trend. However Kumar et al., (2015) reported that baby corn and green fodder yields, economics and nutrient uptake of various nutrients like $\mathrm{N}, \mathrm{P}, \mathrm{K}, \mathrm{S}$ and $\mathrm{Zn}$ were significantly higher with application of $125 \%$ recommended dose of fertilizer (RDF). Shivran et al., (2013) reported that application of $\mathrm{RDF}+60 \mathrm{~kg} \mathrm{~S}^{-1}$ recorded significantly higher seed, stover and biological yields over control. Later on Sharma et al., (2019) reported that the different yield attributes i.e, baby cob length, baby corn length, baby corn girth, baby corn weight (g) plant-1, baby cob weight (g) plant-1, total cob and baby corn yield $\mathrm{q}$ ha-1 and green fodder yield with successive increase in fertility level 180:90:90:5 kg N: $\mathrm{P}_{2} \mathrm{O}_{5}: \mathrm{K}_{2} \mathrm{O}: 5 \mathrm{ha}^{-1}$ in the Indo Gangetic Plains of Bihar.

\section{Effect of N, P, K, S and Zn on economics}

In 2009 Ashoka et al., noticed that application of 150-75-45 kg NPK ha-1 (RDF) +ZnSO4@ $25 \mathrm{~kg} \mathrm{ha}^{-1}$ registered significantly higher gross return, net return and $\mathrm{B}$ : $\mathrm{C}$ ratio over RDF alone. Application of increasing levels of NPKZn up to $250+60+25+10 \mathrm{~kg}$ NPKZn ha ${ }^{-1}$ recorded significantly higher net and B: C ratio over 200-60-31.5-10 kg NPKZn ha ${ }^{-1}$, whereas the lowest was recorded under control according to Paramasivan et al., (2011). Similarly, significantly higher net return and B: $\mathrm{C}$ ratio was observed with application of $100 \%$ RDF (150-60-40 kg NPK 
$\left.\mathrm{ha}^{-1}\right)+25 \mathrm{~kg} \mathrm{ZnSO} 4$ as compared to $100 \%$ RDF (150-60-40 kg NPK ha ${ }^{-1}$ ) alone according to Ashoka and Sunitha in (2011). Later on Kumar et al., (2014) reported that gross return, net return and benefit cost ratio increased significantly with application of $125 \%$ RDF (recommended dose of fertilizer) over $100 \%$ RDF. Recently, Sharma et al., (2019) reported that gross return, net return and benefit cost ratio increased with successive increase in fertility level upto 180:90:90:5 kg N:P $\mathrm{P}_{2} \mathrm{O}_{5}: \mathrm{K}_{2} \mathrm{O}: 5 \mathrm{ha}^{-1}$ in the Indo Gangetic Plains of Bihar.

\section{Effect of INM on growth parameters of baby corn}

The aim of integrated nutrient management (INM) is to optimize the condition of the soil, with respect to its physical, chemical, biological and hydrological properties so that land degradation can be minimised and the productivity of crop can be enhanced. This is now proved that INM not only enhanced the yield but it also conserves the soil resource. Numerous agronomic, vegetative and structural measures designed to conserve both water and soil and the management practices used in the field includes the application of farmyard manures, natural and mineral fertilizers, soil conditioners, soil amendments ,crop residues incorporation and farm waste application, green manures, cover crops, legumes intercropping, crop rotations, fallows, irrigation, drainage, plus a variety of several others. How best to manage soils, nutrients, water, crops and vegetation to improve and sustain soil fertility and land productivity and their processes are derived from the essential soil functions necessary for plant growth is the basic concept behind the management practices.

It is not only in major plant nutrients like nitrogen, phosphorus and in some cases, potash but also in secondary nutrients, like sulphur, calcium, and magnesium our Indian soil is getting deficient. Adding more there are several other micronutrients such as zinc, boron and to a limited extent iron, manganese, copper and molybdenum have also been reported to be deficient in the Indian soil. In the last few decades because of increased use of high analysis fertilizers, use of high yielding crop varieties and increase in cropping intensity deficiency of secondary and micronutrients has grown in both, magnitude and extent, therefore it became a major constraint to production and productivity of crops. So, there is an urgent need for correction of individual nutrient deficiency and for arresting its further spread through INM approach.

Kannan et al., (2013) conducted trial near Pollachi at Vanavarayar Institute of Agriculture and the result showed that, integrated nutrient management has incremental effect on growth parameters of maize such as leaf area and plant height. In the same way, a trial conducted at University of Agriculture Faisalabad, Pakistan, by Ali et al., (2012) at their research trial field and the result showed that the combining ability of poultry manure with single super phosphate result in positive effect on the growth parameter of maize such as leaf area index and crop growth rate. It was reported by Panwar (2008) that, the integrated nutrient management has significant effect on growth parameters of maize crop, which was found in a field trial conducted at ICAR research field Umiam, Meghalaya. Later on, Kumar et al., (2008) reported that application of $120 \mathrm{~kg} \mathrm{~N}$ $\mathrm{ha}^{-1}$ through Urea along with $30 \mathrm{~kg} \mathrm{~N} \mathrm{ha}{ }^{-1}$ through poultry manure resulted in significance increase in growth attributing parameters in maize crop. Similarly, Mahajan et al., (2007) while conducting a field trial at Kangra district of Himachal Pradesh reported that the integrated used of both organic and inorganic manure has positive effect on the 
total productivity of maize crop than sole used of mineral fertilizer. Similarly, Saha and Mondal (2006) in a field experiment at Nadia, WB on influence of integrated plant nutrient supply on baby corn revealed that plant height varied significantly due to INM treatments. The tallest plant was observed with the application of pelleted form of organic matter namely Biomax along with $75 \%$ RDF followed by treatments receiving neem seed powder and FYM along with 75\% RDF compared to $100 \%$ RDF. Rasool et al., (2015) found that application of $75 \%(\mathrm{NPK})+\mathrm{FYM}$ $\left(4.5 \mathrm{t} \mathrm{ha}^{-1}\right)+$ Biofertilizer (Azotobacter + Phosphate solubilizing bacteria (PSB) significantly increased various other growth characters viz., plant height, leaf area index, dry matter, crop growth rate and relative growth rate and the number of days taken to tasseling, silking and milky stages .

A field experiment conducted by Dadarwal et al., (2009) at Udaipur, Rajasthan they evaluated the effect of integrated nutrient management on baby corn showed that maximum plant height and dry matter accumulation were recorded over rest of treatments in the plot with $75 \% \mathrm{NPK}+2.25 \mathrm{t}$ vermicompost $\mathrm{ha}^{-1}$ along with biofertilizer. An experiment was conducted by Keerthi et al., (2013) at Naira, Andhra Pradesh, studied the effect of nutrient management practice on sweet corn and found that application of 180 75-60 kg NPK ha ${ }^{-1}+$ vermiwash at 20, 35, and 50 DAS recorded the highest growth parameters, which was at par with 180-75-60 $\mathrm{kg}$ NPK ha ${ }^{-1}+$ vermicompost. Similarly, Thavaprakash et al., (2005) conducted a field experiment at Coimbatore, observed that integrated nutrient management practices exerted positive influence on growth characters of baby corn. Combined application of $50 \%$ NPK with poultry manure and bio fertilizers (Azospirillum + phosphobacteria) registered taller plants $(183.1 \mathrm{~cm})$, higher LAI $(3.47)$ and dry matter per plant $\left(7543 \mathrm{~kg} \mathrm{ha}^{-1}\right)$.

\section{Effect of INM on yield attributing} characters and yield baby corn

Siddeswaran and Shanmugam (2013) in a field experiment at TNAU, Coimbatore evaluated the performance of different organic farming packages according to results revealed that the combination of both the organics and inorganics in equal proportion of $\mathrm{N}$ equivalent resulted in higher baby corn yield. Meanwhile Lone et al., (2013) from a field experiment at Kashmir observed that application of FYM @ 6t ha ${ }^{-1}$ in combination with $150 \%$ recommended dose of fertilizer 225-90-60 kg N-P $\mathrm{O}_{5}-\mathrm{K}_{2} \mathrm{O} \mathrm{ha}^{-1}$ recorded maximum cob yield (without husk) of $20.60 \mathrm{q}$ $\mathrm{ha}^{-1}$ associated with maximum number of cobs plot $^{-1}$ (326) and green fodder yield Kannan et al., (2013) in their research trial conducted at Vanavavarayar Institute of Agriculture reported that, integrated nutrient management shown the superior result on yield characters of maize like 100 seed weight, number of grain per cob and yield of $4112 \mathrm{Kg} \mathrm{ha}^{-1}$ due to combined effect of vermicompost and recommended dose of NPK. Similarly Ashoka et al., in 2008 reported that integration of RDF (150:75:40 $\mathrm{kg}$ NPK per ha) along with $25 \mathrm{~kg} \mathrm{ZnSO} 4,10$ $\mathrm{kg} \mathrm{FeSO}_{4}$ and $35 \mathrm{~kg}$ Vermicompost on baby corn-chickpea sequence resulted in significantly maximum yield and yield attributes namely; ear length, weight of ear, yield $\left(64.43 \mathrm{q} \mathrm{ha}^{-1}\right)$ as well as green fodder yield $\left(232.33 \mathrm{q} \mathrm{ha}^{-1}\right)$ over sole application of inorganic sources. Furthere, Lone et al., (2013) revealed that integration of $150 \%$ RDF (225:90:69 $\mathrm{kg} \mathrm{NP} \mathrm{ha}^{-1}$ ) along with $6 \mathrm{t} \mathrm{ha}^{-1}$ FYM resulted in production of maximum yield of cob without husk (20.60 ha $\left.{ }^{-1}\right)$. In 2008 Panwar conducted a field trial at ICAR research field Umiam, Meghalaya and reported that, the yield parameters of maize show significant increase with the application of 50 per cent $\mathrm{N}$ each from FYM and recommended doses of NPK. 
Furthermore, in 2008 Bhagade, et al., conducted a field trial at Konkan region of India and they suggested that substitution of 25 per cent recommended doses of fertilizer with FYM will positively result in better green fodder yield production of maize. In 2011 Ghaffari et al., conducted a field trial at central Institute of temperate Horticulture regional station Uttarakhand-India and reported that, the grain yield of maize was significantly increased as a result of the application of different sources of nutrients to the maize plant. In 2005 and 2008 Thavaprakaash et al., conducted a field on baby corn at Tamil Nadu Agricultural University, Combatore and reported that all the yield parameters were significantly increased with the substitution of $50 \%$ NPK through either poultry or goat manure along with Azospirillum and Phosphobacteria. Rasool et al., (2015) revealed from both years of experimentation in the field that the integration of $75 \%(\mathrm{NPK})+\mathrm{FYM} @ 4.5 \mathrm{t} / \mathrm{ha}$ + mixed biofertilizer (phosphate solubilizing bacteria (PSB) + Azotobacter) proved to be significantly superior to rest of the treatments including unfertilized control in increasing cob yield with and without husk, fodder yield and green biomass. This increase may be due to addition of FYM which besides supplying all the essential nutrients might have also improved the physico-chemical properties of the soil. Similar effect was noticed by Singh et al., (2010) worked on babycorn at Varanasi.

\section{Effect of INM on economics of baby corn}

Saha and Mondal (2006) conducted the experiment at Nadia, WB on influence of integrated plant nutrient supply on baby corn revealed that net return and benefit: cost ratio of baby corn increased with the application of $75 \%$ RDF along with each of pelleted form of organic manure, neem seed powder and FYM over $100 \%$ RDF.
The results of a field experiment on influence of integrated nitrogen management on yield, nitrogen uptake, soil fertility status and economics of baby corn at Tirupati revealed that application of 100 per cent $\mathrm{N}$ through fertilizer recorded highest net return and benefit: cost ratio in baby corn which was at par with 75 per cent $\mathrm{N}$ through fertilizer along with $25 \% \mathrm{~N}$ through poultry manure or sheep manure or farm yard manure Kumar et al., (2009). A field experiment conducted by Dadarwal et al., (2009) at Udaipur, Rajasthan to evaluate effect of integrated nutrient management on baby corn showed that significantly higher net return Rs.26815 ha ${ }^{-1}$ and benefit: cost (2.83:1) were recorded under $75 \% \mathrm{NPK}+2.25 \mathrm{t}$ vermin compost $\mathrm{ha}^{-1}$ along with biofertilizer. Lone et al., (2013) from a field experiment at Kashmir observed that application of farm yard manure (FYM) at $6 \mathrm{t}$ $\mathrm{ha}^{-1}$ in combination with $150 \%$ recommended dose of fertilizer (90N:60P2O5: $40 \mathrm{~K} 2 \mathrm{O} \mathrm{kg}$ $\mathrm{ha}^{-1}$ ) recorded maximum $\mathrm{B}$ : C ratio of 1:1.59.

Sharma and Banik (2014) conducted trial on Arbuscular Mycorrhiza, Azospirillum and chemical fertilizer application to baby corn at Indian Statistical Institute, Kolkata revealed that benefit: cost ratio were higher with $50 \%$ RDF (150-60-60 kgN-P $\left.2 \mathrm{O}_{5}-\mathrm{K}_{2} \mathrm{O} \quad \mathrm{ha}^{-1}\right)+$ Arbuscular Mycorrhiza + Azospirillum. In a field experiment at TNAU, Coimbatore Siddeswaran and Shanmugam (2013) evaluated the performance of different organic farming packages and the observations were made that the combination of both the organic and inorganic (50\% each) resulted in higher net return and $\mathrm{B}$ : $\mathrm{C}$ ratio due to less cost involved in nutrient application as compared with different organic farming packages.

\section{Effect of INM on soil fertility status}

Ghaffari et al., (2011) reported that, the nutrients use efficiency was improved up to 
$11.5 \%$ due to combined effect of recommended dose of NPK along with single spray of multinutrients. Singh et al., (2010) reported that with application of $180 \mathrm{Kg} \mathrm{N}$ $+38.7 \mathrm{Kg} \mathrm{P}_{2} \mathrm{O}_{5}+74.7 \mathrm{Kg} \mathrm{K} 2 \mathrm{O}$ per ha and $50 \% \mathrm{~N}$ supplied through FYM resulted in significant increase in available NPK in soil after harvesting baby corn. Sarwar et al., (2012) reported that, both organic matter content and available nutrients in the soil was increased either 25 or 50 per cent of $\mathrm{N}$ is replace with FYM.

Rao et al., (2010) also suggested that, the integrated application of nutrients in maize grown under rain fed maintain and sustain soil resources. The nutrients (NPK) uptake was found to be significantly higher due to integration of $50 \%$ RDF along with either poultry manure or FYM than sole application of $100 \%$ RDF (Thavaprakaash, et al., 2007). Shilpashree et al., (2012) revealed that, in addition to release of plant nutrients from organic matter, the organic acid produce during decomposition process also release the native nutrients on soil and increases their availability to plant. Ebrahimpour et al., (2011) reported that, significance increased of soil nutrients were observed due to use of biofertilizer and they concluded that nonchemical sources of crop nutrition provide a reliable alternative to chemical fertilization in organic crop production.

Dadarwal et al., (2009) reported that, continuous application of FYM enhances the availability of NPK status of soil after harvest of baby corn. Later on Kannan, et al., (2013) conducted a field trial at Vanavavarayar Institute of Agriculture and the result shows that, integrated nutrient management significantly influenced the maximum increase in organic carbon as a result of integrated used of vermicompost and recommended dose of NPK. In a field trial conducted at University of Agriculture
Faisalabad Pakistan in their Agronomic trial field and the result shows that integrated nutrient management is one of the good approach for nutrients management in the environmental balance (Ali et al., 2012). Similarly, Rasool (2015) revealed from both years of experimentation in the field that the integration of $75 \%(\mathrm{NPK})+\mathrm{FYM} @ 4.5 \mathrm{t} / \mathrm{ha}$ + mixed biofertilizer (phosphate solubilizing bacteria (PSB) + Azotobacter) improved the physico-chemical properties of the soil. Later on similar report suggested by Ravichandra et al., (2016) with application 100\% RDF N and $12.5 \mathrm{t} \mathrm{ha}^{-1}$ FYM during both the seasons.

Thus, it can be concluded that the integration of different sources of nutrients either from inorganic, organic and biofertilizers recorded higher growth, yield and economics rather than sole use of either chemical fertilizers or organic manures. All most of the researchers had suggested fertility level of $150-180 \mathrm{~kg}$ Nitorgen, 60-90 kg $\mathrm{P}_{2} \mathrm{O}_{5}, 60-90 \mathrm{Kg} \mathrm{K}_{2} \mathrm{O} 30-40$ $\mathrm{kg}$ Sulphur and 5-10 kg Zn ha ${ }^{-1}$ for higher baby corn yield, fodder yield, nutrient content and monetary returns to the growers. However, substitution of $25 \%$ nitrogen by organic sources viz., FYM/ vermicompost along with biofertilizers was more beneficial for baby corn yield, fodder yield, economics and improved soil fertility status.

\section{References}

Ali M, Ali A, Tahir M, Yaseen M. (2012) Growth and Yield Response of Hybrid Maize through Integrated Phosphorous Management. Pakistan Journal of Life and Social Sciences. 2012; 10(1):59-66.

Ashoka P, Mudalagiriyappa Pujari BT, Hugar PS, Desai BK.(2008) Effect of Micronutrients With or Without Organic Manures on Yield of Baby Corn (Zea mays L.)- Chickpea (Cicer artietinum L.) Sequence. Karnataka Journal of Agricultural Science. 21(4):485487.

Ashoka P, Nanda SR, Mudalagiriappa Smitha R.(2009) Effect of macro and micro 
nutrients with organics on growth, quality, yield and economics of baby corn (Zea mays). Crop Research. 37(1-3):15-18.

Ashoka, P. and Sunitha, M.N.H. (2011). Effect of different nutrient management practices on yield, economics and nutrient uptake of baby corn (Zea mays L.). Res. Crops, 12:368-371.

Bhagade HS, Rajemahadik VA, Akhave SR(2008) Integrated Nutrient Management Studies on Growth, Quality and Yield of Fodder Maize in Konkan Region. International Journal of Agricultural Sciences. 4(2):513-515.

Chapagain Tejendra. (2009) Effect of Integrated Plant Nurient Management (IPNM) Practices on the Sustainability of Maizebased Hill Farming Systems in Nepal. University of British Columbia, Faculty of Land and Food Systems,

Dadarwal RS, Jain NK, Singh D.(2009) Integrated Nutrient Management in Baby Corn (Zea mays). Indian Journal of Agricultural sciences. 79(12):1023-5.

Ghaffari A, Ali A, Tahir M, Waseem M, Ayub M, Iqbal A (2011). Influence ofIntegrated Nutrients on Growth, Yield and Quality of Maize (Zea mays L.). American Journal of Plant Sciences. 2:63-69.

Jeet, S., Singh, J.P. Kumar, R. and Om, H. (2014) Response of nitrogen and sulphur levels on productivity and profitability of QPM hybrid (Zea mays) under dryland condition of Eastern Uttar Pradesh. Indian J, Agric, Sci., 84: 589-594.

Keerthi S, Upendra Rao A, Ramana AV, Tejeswara RK.(2013) Effect of nutrient management practices on cob yield, protein content, NPK uptake by Sweet corn and post-harvest $\quad \mathrm{N}, \quad \mathrm{P}_{2} \mathrm{O}_{5}$ and $\mathrm{K}_{2} \mathrm{O}$. International Journal of Advanced Biological Research. 3(4):553-555.

Kumar A, Singh R, Rao LK, Singh UK. (2008) Effect of Integrated Nitrogen Management on Growth and Yield of Maize (Zea mays L.) cv. PAC-711. Madras Agricultural Journal. 95(7-12):467-472.

Kumar R, Bohra JS.(2014) Effect of NPKS and $\mathrm{Zn}$ application on growth, yield, economics and quality of baby corn. Archives of Agronomy and soil science. 60 (9):11931206.
Kumar R., Bohra JS., Singh AK. and Kumawat N.(2015) Productivity, profitability and nutrient-use efficiency of baby corn (Zea mays) as influenced of varying fertility levels. Indian J. Agron., 60:285-290.

Kumar S., Kumar A., Singh J and Kumar P. (2016) Growth indices and nutrient uptake of fodder maize (Zea mays L.) as influenced by integrated nutrient management. Forage Res. 42(2): 119-123.

Lone AA, Allai BA, Nehvi FA.(2013) Growth, yield and economics of baby corn (Zea mays L.) as influenced by Integrated Nutrient Management (INM) Practices. African Journal of agricultural Research. 8(37):4537-4540.

Mahajan S, Kanwar SS, Kumar P, Sharma SP.(2007) Long Term Effect of Mineral Fertilizers and Amendments on Mmicrobial Dynamics in an Alfisol of Western Himalayas. Indian Journal of Microbiolog. 47:86-89.

Meena SR, Kumar A, Jat BP, Meena BP, Rana DS, Idanani LK.(2012) Influence of nutrient sources on growth, productivity and economics of baby corn (Zea mays)potato (Solanum tuberosum)-mung bean (Vigna radiate) cropping system. Indian Journal of Agronomy. 57(3):217-221.

Panwar AS.(2008) Effect of Integrated Nutrient Management in Maize (Zea mays)-Mustard (Brassica compestris var toria) Cropping System in Mid Hills Altitude. Indian Journal of Agricultural Sciences. 78(1):2731.

Paramasivan, M., Kumaresan, K.R., Malarvizhi, P., Mahimairaja, S. and Velayudham, K. (2010). Effect of different levels of NPK and $\mathrm{Zn}$ on yield and nutrient uptake of hybrid maize (COHM 5) in Mayamankuruchi (Myk) series of soil of Tamil Nadu. Asian J. Soil Sci., 5:157-161.

Paramasivan, M., Kumarsesan, K.R. and Malarvizhi, P. (2011). Effect of balanced nutrition on yield, nutrient uptake and soil fertility of maize (Zea mays) in vertisol of Tamil Nadu. Indian J. Agron., 56:133-137.

Rasool S, Kanth RH, Hamid S, Raja W, Alie BA, Dar ZA.(2015) Influence of Integrated nutrient management on growth and yield of sweet corn (Zea mays L. Saccharata) 
under temperate conditions of Kashmir valley. American Journal of Experimental Agriculture. 7(5):315-325.

Ravi N, Basavarajappa R, Chandrashekar CP, Harlapur SI, Hosamani MH, Manjunata MV (2012). Effect of Integrated Nutrient Management on Growth and Yield of Quality Protein Maize. Karnataka Journal of Agricultural Sciences. 25(3):395-396.

Ravichandran S., Suresh Kumar R. and Hariharasuthan V. (2016). Growth, yield and economics of baby corn (zea mays 1.) as influenced by plant population and integrated nitrogen management. International Journal of Agriculture Sciences. 8(53): 2774-2776

Saha M, Mondal SS.(2006) Influence of integrated plant nutrient supply on growth, productivity and quality of baby corn (Zea mays) in Indo-Gangetic plains. Indian Journal of Agronomy. 51(3):202-205.

Sharma Alka Jyoti, Singh MK, Kumar Sanjay and Shambhavi Shweta (2019). Effect of Plant Geometry, Fertility level and Zinc Level on Kharif Baby corn (Zea mays L.). Int.J.Curr.Microbiol.App.Sci. 8(7): 16581667

Sharma Alka Jyoti, Singh MK, Kumar Sanjay and Shambhavi Shweta (2020). Response of Plant Geometry, Graded Fertility and Zinc Level on Productivity, Profitability and Quality of Rainfed Baby corn (Zea mays L.) in Bihar. Int.J.Curr.Microbiol.App.Sci. 9(2): 2085-2092

Sharma RC, Banik.(2014) Vermicompost and
Fertilizer Application: Effect on productivity and profitability of baby corn (Zea mays L.) and soil health. Compost Science \& utilization. 22:83-92.

Shivran, RK, Kumar R. and Kumari A. (2013). Influence of sulphur, phosphorus and farm yard manure on yield attributes and productivity of maize (Zea mays L.) in humid south eastern plains of Rajasthan. Agric. Sci. Digest, 33:9-14.

Siddeswaran K, Shanmugam PM. (2013) Organic nutrient management in ChilliesBengalgram-baby corn sequence. International Journal of Agricultural sciences and Veterinary Medicine. 1(3):122-126.

Singh M.K., Singh RN, Singh SP, Yadav MK and Singh VK. (2010) INM for higher yield, quality and profitability of baby corn (Zea mays). Indian Journal of Agronomy 55:100-104.

Thavaprakaash N, Velayudham K. and Muthukumar VB (2008). Response of Crop Geometry, Intercropping Systems and INM Practices on Yield and Fodder Quality of baby corn. Asian Journal of Scientific Research, 1 (2): 153-159.

Thavaprakaash N, Velayudham K. and Muthukumar VB. (2005) Effect of crop geometry, intercropping system and integrated nutrient management practices on productivity of baby corn (Zea mays L.) based intercropping systems. Res. J. Agric. Biol. Sci., 1:295-302.

\section{How to cite this article:}

Alka Jyoti Sharma, M. K. Singh, Nirpendra Pratap Singh, Sneha and Akanksha Raj. 2020. Response of Integrated Nutrient Management on Babycorn (Zea mays L.) - A Review. Int.J.Curr.Microbiol.App.Sci. 9(05): 3329-3338. doi: https://doi.org/10.20546/ijcmas.2020.905.396 